Research Article

\title{
A Descriptive Study to Assess the Knowledge regarding Home Based Care of Corona Positive Patients (Mild, Pre-symptomatic) and Quarantined People among the Students of Selected Nursing College, New Delhi
}

\author{
Rashmi
}

Tutor, Rufaida College of Nursing, School of Nursing Science and Allied Health, Jamia Hamdard (Deemed to be University), New Delhi, India.

DOI: https://doi.org/10.24321/2455.9318.202020

\section{I $\quad \mathbf{N} \quad \mathbf{F} \quad \mathbf{O}$}

E-mail Id:

rashmirohilla2@gmail.com

Orcid Id:

https://orcid.org/0000-0002-9213-9469

How to cite this article:

Rashmi. A Descriptive Study to Assess the Knowledge regarding Home Based Care of Corona Positive Patients (Mild, Pre-symptomatic) and Quarantined People among the Students of Selected Nursing College, New Delhi. Int J Nurs Midwif Res 2020; 7(3): 12-15.

Date of Submission: 2021-01-02

Date of Acceptance: 2021-03-03

\section{$\begin{array}{llllllll}\mathbf{A} & \mathbf{B} & \mathbf{S} & \mathbf{T} & \mathbf{R} & \mathbf{A} & \mathbf{C} & \mathbf{T}\end{array}$}

\begin{abstract}
A descriptive study was conducted to assess the knowledge regarding home based care of corona positive patients (mild, pre symptomatic) and quarantined people among the students of selected nursing college. Objective of the study was to assess the knowledge of students regarding home based care of corona positive patients (mild and pre-symptomatic) and quarantined people. By using non experimental descriptive research design it was conducted among 79 subjects who were studying in DGNM $2^{\text {nd }}$ year and DGNM $3^{\text {rd }}$ year of Rufaida College of Nursing by non probability convenience sampling technique. The tool developed for the data collection was a self structured knowledge questionnaire. The data was analyzed using descriptive statistics. Findings revealed that out of 79 subjects, $84.81 \%$ had average knowledge followed by $11.39 \%$ having good knowledge, $2.53 \%$ having poor knowledge and $1.27 \%$ having excellent knowledge regarding home based care of corona positive patients (mild, pre-symptomatic) and quarantined people.
\end{abstract}

Keywords: Quarantine, Isolation, Home Based Care

\section{Introduction}

Corona virus is related to a large family group of viruses which may cause illness in animals or humans. In humans, novel corona virus directly attacks the upper respiratory tract and it may cause respiratory infections, from common cold to more severe diseases like Middle East Respiratory Syndrome (MERS) and Severe Acute Respiratory Syndrome (SARS).
The most recently spread virus/ disease was unknown until its outbreak began in Wuhan, China, in December 2019. ${ }^{1}$ The WHO (World Health Organization) declared COVID-19 a pandemic on 11 March, 2020. ${ }^{2}$ Worldwide COVID 19 exploded to $33,688,356$ cases and caused 1,008,600 deaths by August 2020. The reason behind this (generation of COVID-19) was linked to Wuhan's wholesale market of 
seafood, the market which trades all variety of fishes, live animal species including bats, mammals, poultry and snakes in bulk for retail selling. The causative agent of COVID-19 was identified by taking throat swab sampling which was firstly conducted by Chinese Centre of Disease Control (CCDC) on $7^{\text {th }}$ January $2020 .^{2}$

COVID-19 is now a pandemic affecting many countries globally. ${ }^{1}$ Governments around the world are taking many efforts to control the spread of COVID-19. A major part of these efforts applied by government of India is selfquarantine. Those people who may have been exposed to COVID-19 are instructed to self quarantine for a period of 14 days minimum, which can prevent them from having interaction with other people. Isolation is separating people who are known to be ill from other people who are not ill. Self quarantine can be effective in controlling the spread of this disease, as it did with SARS in $2003 .^{3}$

Self isolation is an important measure taken by those who have COVID-19 symptoms to avoid infecting others in the family, society, and community. Meaning of quarantine is restricting activities or separating people who are not ill but may have been exposed directly or indirectly to COVID-19. In India the first case of COVID-19 was reported on $30^{\text {th }}$, January 2020. India currently has the largest number of confirmed cases in Asia, and has the third highest number of confirmed cases with the number of total confirmed cases reaching the 100,000 mark on $19^{\text {th }}$ May; 200,000 on $3^{\text {rd }}$ June and 3,000,000 confirmed cases on $17^{\text {th }}$ July 2020.

It is unfortunate that there is no validated curative therapy such as vaccine or specific drug against COVID-19 so far. As a result, screening, isolation, symptomatic and supportive care are the major treatment procedures. The methods adopted according to the condition of the patient among the different aspects of area, the results shows that the cases have rapidly increased with thousands number of morbidity rate especially the age above 60 years and the patient with different disease like cardiovascular, diabetes mellitus, cerebrovascular accidents. Simultaneously the cases of improved patients have also increased. ${ }^{4}$

The large number of population has been quarantined and isolated to prevent the further transmission. The control of disease by proper precautions, management, and care can decrease the cases. Therefore the quarantine zone was essential to practice and follow up the safety measurement regarding protection from virus. The government passed a rule of social distancing and closed certain places like cinemas, school and institutional area to minimize the transmission of disease. ${ }^{5}$

Basic hand hygiene and basic safety measurements included frequent hand washing for 60 seconds and practices of using hand sanitizer and the most important is use of PPE such as face masks. ${ }^{6}$
As per the research, only the $6 \%$ cases need hospitalization and rest $94 \%$ of cases need good care during home isolation with maintaining all the respective safety measurements and consumption of healthy nutritive diet, and by monitoring vital signs every hour. Hence, the present study was undertaken with the objective to assess the knowledge of students regarding home based care of Corona positive patients (mild and pre-symptomatic) and quarantined people.

\section{Materials and Methods}

The study was conducted in August 2020. The research approach adopted for the study was non experimental descriptive research design. The tool developed for the data collection was a self structured questionnaire. Non probability convenience sampling technique was adopted to select the subjects. The sample consisted of 79 subjects from the selected nursing college of New Delhi. Selfstructured Questionnaire was used to collect data for assessing the knowledge of student nurses which consisted of two sections. Section I consisted of 8 items to collect the information on student demographic data such as age in years, gender, name, of course, religion, area of residence, source of previous knowledge related to home-based care of corona positive patients(mild and pre-symptomatic) and quarantined persons and if anyone in the family had been infected with COVID-19? Section II consisted of 30 multiple choice questions to assess the knowledge of students regarding Home-based care of Corona positive patients (mild and pre-symptomatic) and quarantined people. The data was analyzed using descriptive statistics.

\section{Result}

\section{Section A}

This section shows the characteristics of nursing students on the basis of demographic variables like age, gender, course/ year, religion, area of residence etc.

Table I.Distribution of students according to their demographic variables

$(n=79)$

\begin{tabular}{|c|c|c|}
\hline Demographic variable & $\begin{array}{c}\text { No of student } \\
\text { (Frequency) }\end{array}$ & $\begin{array}{c}\text { Percentage } \\
\%\end{array}$ \\
\hline \multicolumn{3}{|c|}{ Age (years) } \\
\hline $17-19$ & 4 & $5.06 \%$ \\
\hline $20-22$ & 62 & $78.48 \%$ \\
\hline $23-25$ & 13 & $16.46 \%$ \\
\hline 26 and Above & 0 & $0.00 \%$ \\
\hline \multicolumn{3}{|c|}{ Gender } \\
\hline Male & 21 & $26.58 \%$ \\
\hline
\end{tabular}




\begin{tabular}{|c|c|c|}
\hline \multicolumn{3}{|c|}{ Nemale of course } \\
\hline \multicolumn{3}{|c|}{ Religion } \\
\hline DGNM & $25.42 \%$ \\
\hline Hindu & 49 & $100 \%$ \\
\hline Muslim & 1 & $62.02 \%$ \\
\hline Christian & 4 & $5.06 \%$ \\
\hline Other & 68 & $86.07 \%$ \\
\hline Area of residence & $13.93 \%$ \\
\hline Urban & 11 & \\
\hline Rural & & \\
\hline
\end{tabular}

Previous knowledge related to home based care

\begin{tabular}{|c|c|c|}
\hline Yes & 79 & $100 \%$ \\
\hline \multicolumn{2}{|c|}{ If yes to question 6, source of information } \\
\hline $\begin{array}{c}\text { Online seminar/ } \\
\text { Conference }\end{array}$ & 37 & $46.84 \%$ \\
\hline $\begin{array}{c}\text { Newspaper/ Media } \\
\text { Friends/ Teacher }\end{array}$ & 23 & $29.11 \%$ \\
\hline Healthcare Worker & 4 & $18.99 \%$ \\
\hline \multicolumn{2}{|c|}{ Has anyone in your family been infected with } \\
CoVID-19? & $15.06 \%$ \\
\hline Yes & 8 & $10.13 \%$ \\
\hline No & 71 & $89.87 \%$ \\
\hline
\end{tabular}

\section{Section B}

This section deals with assessment of knowledge of participant regarding home based care of corona positive patients (mild \&pre-symptomatic) and quarantine people. The level of knowledge is divided under following headings poor, average, good, excellent Knowledge.

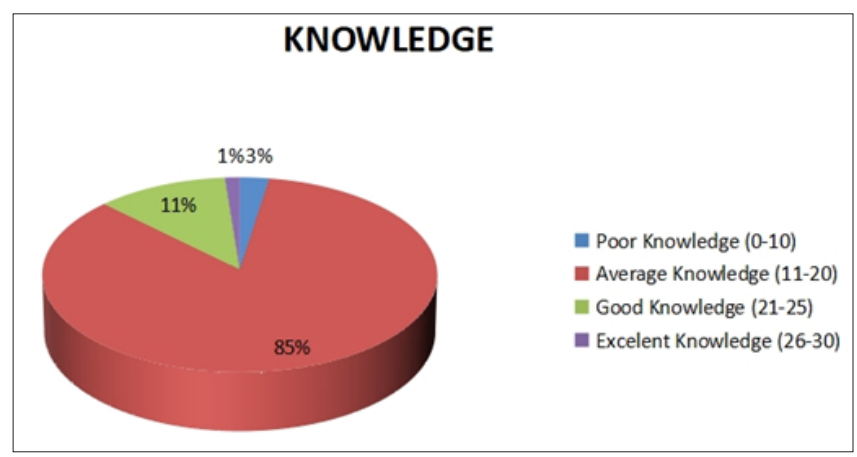

Figure I.A pie diagram representing percentage of participant's knowledge

The data was collected on 79 sample in which $84.81 \%$ had average knowledge followed by $11.39 \%$ good knowledge and $2.53 \%$ poor knowledge and $1.27 \%$ excellent knowledge related to home based care of Corona positive patients (mild \& pre-symptomatic) and quarantined person. The minimum score was 6 out of 30 and maximum 29. Mean was 16.97 and median 17 and standard deviation as 3.48.

\section{Discussion}

The current study was designed to assess the knowledge of students regarding home-based care of corona positive patients (mild \& pre-symptomatic) and quarantined people. This study shows that $84.81 \%$ students had average knowledge regarding the home-based care. Results of the present study are in line with the findings of the study conducted by Elgendy MO, Abd Elmawla MN. The study aimed to evaluate awareness and practice related to the COVID 19 Quarantine instructions among the home quarantine COVID 19 patients, and persons who contacted them during home quarantine. Results showed that home quarantined COVID 19 patients and people in close contact with them in the study had good knowledge and awareness of home quarantine instructions, instruction for family members of infected patients. ${ }^{7}$

It is evident from the current study that $84.81 \%$ subjects had average knowledge regarding home-based care of Corona positive patients (mild \& pre-symptomatic) and quarantined people, and only $11.39 \%$ were had good knowledge. These results are in partial agreement with the study conducted by Rani $\mathrm{S}$ et al. to assess the knowledge and practice of community regarding prevention of Corona Virus Infectious Disease. An online survey was conducted to collect the data by using a structured questionnaire to assess knowledge and expressed practice regarding prevention of COVID-19. Results showed that $98.8 \%$ of the subjects had adequate knowledge and $99.8 \%$ had appropriate expressed practice regarding prevention of corona virus disease. This indicates that community has good knowledge and practice as expressed by them. Further, findings showed that there was a positive correlation between the knowledge and practice of community regarding prevention of COVID-19. ${ }^{8}$ Higher level of knowledge in the current as well as the quoted study may be due to the wide spread information about COVID 19 through media and news channels.

On the basis of the findings of the study the following recommendations are offered for future research. A similar study can be conducted on large sample to draw generalization. The study was conducted on small number of subjects, which limits the generalization of the findings of the study.

\section{Acknowledgement}

I take the opportunity to place on records the hard work and the tireless efforts in data collection and compilation of the data of DGNM students of Rufaida College of Nursing, 
Jamia Hamdard namely Ms. Alice Tirkey, Ms. Amkamsoom, Ms. Anushita Sharma, Ms. Deepanshi Rajpoot, Mr. Faizul Haq, Mr. Gopal, Ms. Gulshan, Ms. Gulista and Ms. Hameeda.

Conflict of Interest: None

\section{References}

1. Coronavirus disease (COVID-19) pandemic. Available from: https://www.who.int/emergencies/diseases/ novel-coronavirus-2019.

2. Chatterjee K. Healthcare impact of COVID-19 epidemic in India: a stochastic mathematical model. Med J Armed Force India 2020; 76(2): 147-55.

3. Worldometer's COVID-19 data. Available from: https:// www.Worldometer.info/coronavirus/.

4. Novel Coronavirus - China. Available from: https:// www.who.int/csr/don/12-january-2020-novelcoronavirus-china/en/.

5. Gopal D. Life-saving importance of Quarantine, Narayana Health. 2020. Available from: https://www. narayanahealth.org/blog/life-saving-importance-ofquarantine/.

6. Pathak N. Coronavirus and COVID-19: What You Should Know. 2020. Available from: https://www.webmd.com/ lung/coronavirus.

7. Bodas M, Peleg K. Self-isolation compliance in the COVID 19 Era influenced by compensation: finding from a recent survey in Israel. Health Affairs 2020; 39(6).

8. Rani S, Bhattacharya S, John A et al. A descriptive study to assess the knowledge and expressed practice of community regarding prevention of Corona Virus disease. Journal of Communicable Disease 2020; 52(2): 32-37. 